ECONOMIC THEMES (2019) 57(4): 497-510

\title{
THE EFFECTS OF EMPLOYEES' EDUCATION DEGREE ON THE CORRELATION BETWEEN JOB SATISFACTION AND PERSONALITY DIMENSIONS
}

\author{
Milena Nedeljković Knežević \\ University of Novi Sad, Faculty of Sciences, \\ Department of Geography, Tourism and Hotel Management, \\ $\bowtie$ milena.nedeljkovic3@gmail.com \\ Slađana Nedeljković \\ JP EPS, Ogranak RB 'Kolubara' \\ $\triangle$ slakospo@gmail.com \\ Maja Mijatov \\ University of Novi Sad, Faculty of Sciences, \\ Department of Geography, Tourism and Hotel Management, \\ $\bowtie$ majamijatov@gmail.com
}

UDC
005.32:331.
101.32)

Original scientific paper

\begin{abstract}
Employees' job satisfaction is an important factor of shaping the organizational business performances. However, job satisfaction might depend on employees' personality dimensions, such as: extraversion, negative affectivity, conscientiousness, agreeableness and openness to new experiences. Besides that, the employees' job satisfaction, but also their personality dimensions, might be affected by the employees' education degree. In respect to that, this research was oriented towards determining the effects of the employees' education degree on the correlation between the employees' job satisfaction and their personality dimensions. The survey research sample consisted of 116 respondents, employed within a large public monopolistic organization, oriented towards the energy sector, operating in transitional society. The research results indicated that employees' education degree shaped the correlation between all personality dimensions, on the one hand, and the pay, benefits, relation between coworkers, supervision and nature of the work facets of job satisfaction, on the other. Beside theoretical contribution, the research results might have practical implication through providing the information necessary for improving human resource management in Serbia, a transitional economy with general business conditions different from those in developed countries.
\end{abstract}


Received: Keywords: job satisfaction, personality dimensions, Big Five theory, 28..3.2019 education degree, transitional economy

JEL classification: D79, D91, J53, J8, M12, M54, Z32, Z39.

\section{Introduction}

In contemporary business conditions, employees represent a strategic resource of majority organizations (Héder et al., 2018), while their job satisfaction might be considered as a precondition of gaining the business success (Burgess \& Nyajeka, 2007; Chi \& Gursoy, 2009), usually reflected in the form of the organizational business performances (Fu \& Deshpande, 2014). However, the employees' job satisfaction might vary, depending on different psychological constructs, including the widely used psychological Big Five theory of personality dimensions (Judge \& Zapata, 2015; Hahn et al., 2016). Previous research indicated that personality dimensions might affect the employees' job satisfaction (Judge \& Zapata, 2015), but there are also studies that confirmed the effect of the employees' education degree on job satisfaction (Szivas et al., 2003) and personality dimensions (Rammstedt et al., 2016).

The main subjects of this study are dimensions of the employees' personality, according to Big Five theory and their job satisfaction, while the main task of the study is oriented towards researching their correlation, considering the employees' education degree as a socio-demographic characteristic that could shape the correlation of the main constructs of the research. The research was conducted within a large public-owned organization operating in the energy sector of Serbia, facing the organizational changes (i.e. privatization), which might affect the employees' job satisfaction, mostly in a negative way. This kind of research is particularly important for the organizations that are operating in transitional societies, facing specific problems which may not be evident within the societies with stable economic and political conditions (Van den Berg \& Pitariu, 2003; Sun et al., 2018).

\section{Literature review}

\subsection{Job satisfaction}

One of the widely used definitions of job satisfaction is pointing out that this construct is related to the employees' positive emotional state, arising from the evaluation of the job or overall work experience (Locke, 1976). Cronin et al. (2000) even indicated that job satisfaction is a key variable that might affect the employees' attitudes and behaviours. It could be said that there is no single attitude on general aspects of job satisfaction that should be considered, when researching this construct (Burke et al., 2005). However, Spector (1997) is indicating some of 
the most frequently mentioned facets of job satisfaction, such as: pay, promotion, supervision, benefits, rewards, operating conditions, relation with co-workers, the nature of work and communication. These facets were also researched for the purpose of this study in a combination with the employees' personality dimensions and their correlation.

\subsection{Personality dimensions}

The psychology of personality is related to the nature of fundamental dimensions of individual's character and one of the widely used approaches to this subject is represented in the form of the Big Five theory, that includes personality dimensions, such as: extraversion, negative affectivity, conscientiousness, agreeableness and openness to new experiences (Walker \& Vetter, 2016; Atari et al., 2017). Extraversion is characterized by cheerfulness (activity), cordiality, sociability and the dominance of empathy. An extravert person is oriented towards establishing the interactions with other people and such persons are open to new experiences (Liang et al., 2015). Negative affectivity is characterized by the focus on the negative aspects of other people. In general, it could be said that this dimension is distinguished by the lack of emotional stability, the feeling of pressure, dissatisfaction and concern (İrengün \& Arıbboğa, 2015; Liang et al., 2015). Conscientiousness is characterized by sub-dimensions, such as respecting the rules, systematically planning and performing the tasks, inflexibility and conformism. Thus, it could be said that individuals with high degree of conscientiousness are responsible, self-disciplined and persistent (Liang et al., 2015). Agreeableness is characterized by the establishment of closeness with other people. It could be said that this dimension of personality is characterized by consideration and tenderness toward others, but also by conflict avoidance and willingness to forgive (Antoncic et al., 2015). Openness to new experiences is characterized by creativity and an ability to think in unconventional way, including a simple adaptation to different changes. Thus, the sub-dimensions of openness to new experiences are independence, intellectual efficiency and intellectual curiosity (Antoncic et al., 2015; İrengün \& Arıkboğa, 2015; Liang et al., 2015).

\subsection{Personality dimensions and job satisfaction}

Previous findings suggested that personality dimensions could affect the employees' job satisfaction (Judge \& Zapata, 2015; Bui, 2017). It means that employee often feel pressure to behave contrary to their personal characteristics. Despite the fact that threatening the individual values could sometimes enable the employees to progress within the organizational hierarchy, that feeling could decrease their job satisfaction, at the same time. On the other hand, if personality dimensions are in line with the values established within the organization, their job satisfaction might increase (Lopez et al., 2009; Arthaud-Day et al., 2012). 
There are numerous issues related to identifying and understanding the factors that might increase the employees' motivation and their job satisfaction (AleksićGlišović et al., 2019). Furthermore, the research conducted by Ivanović-Đukić, Đorđević and Lepojević (2018) was oriented towards identifying the mediating effects of educational level on job related characteristics - job satisfaction relationship. Also, previous findings indicated the impact of Big Five personality traits and positive psychological strengths towards job satisfaction (Therasa \& Vijayabanu, 2015), where the predicting influence of these personality traits, according to Big Five theory, was confirmed.

\subsection{Predictors in Shaping the Job Satisfaction}

Factors that could influence an increase or decrease in job satisfaction might be related to the employees' socio-demographic characteristics (Maruping \& Magni, 2012; Li \& Chang, 2016). Thus, one of the socio-demographic characteristics that could affect the employees' job satisfaction is the level of their education. Employees with higher level of education might have higher expectations in terms of their job satisfaction, which could make its achievement difficult. Also, the level of job satisfaction could be lower in situations when the employees' education is not from the field related to contemporary business position, or when their education degree is higher in comparison with the education degree that is necessary for performing certain business tasks (Szivas et al., 2003). On the other hand, Frye and Mount (2007) indicated that education degree has minimal impact on the level of job satisfaction.

In addition to the impact of education degree on shaping the employees' job satisfaction, the impact of this socio-demographic characteristic could also be noticed in shaping the personality dimensions. Thus, according to the research results, higher education degree might increase the employees' openness to new experiences (Rammstedt et al, 2016).

In accordance with the previous findings, this research was oriented towards the determination of the effect of the socio-demographic variable 'education degree' on the correlation between the employees' personality dimensions, according to the model of the Big Five and individual facets of their job satisfaction.

\section{Methodology}

\subsection{Instrument}

The research was conducted using the questionnaire, especially constructed for the purpose of this research. The questions could be grouped into the three parts. The first part of the questionnaire was related to the respondents' socio-demographic characteristics, with the respondents' education degree as the most important 
characteristic of this research. The second group consisted of 25 items related to five personality dimensions, such as: extraversion, negative affectivity, conscientiousness, agreeableness and openness to new experiences, according to the scale developed by Howard and Howard (2000). Finally, the third part was related to 36 items of the respondents' job satisfaction, constructed by Paul Spector (Spector, 1997), and related to nine facets of job satisfaction: pay, promotion, supervision, benefits, rewards, operating conditions, relation between co-workers, the nature of work and communication. The respondents expressed a degree of their agreement or disagreement with previously mentioned statements on the scale from 1 (I completely disagree) to 6 (I completely agree).

\subsection{Procedure}

The research was conducted during 2016, within a Serbian public-owned organization operating in the energy sector, in a small town that is almost completely oriented towards this energy complex. All respondents participated in the survey research voluntarily. At the beginning, they were informed that the research was anonymous and that results would be used only for the purpose of science. Obtained data were analysed by using the Statistical Program for Social Sciences (SPSS 17.0), with the focus on determining the effects of the employees' education degree on the correlation between the main research constructs, personality dimensions and job satisfaction.

\subsection{Sample}

The total sample of the research consisted of 116 respondents out of 11880 employees. According to the employees' education degree, the most important socio-demographic characteristic of this research, $32.8 \%$ of the respondents is with high school education degree. Beside the respondents with a high school diploma, there is also $11.2 \%$ of the respondents who gained a college degree of education (two-years studies) and $56 \%$ of the respondents with a faculty education degree (four-years study). For the purpose of this research, the respondents with high school education degree were considered a part of the group of the employees without higher education degree, while the respondents with college and faculty education degree were considered the employees with higher education.

\section{Results}

Mean values and standard deviations for all measured personality dimensions (extraversion (E), negative affectivity $(\mathrm{N})$, conscientiousness $(\mathrm{C})$, agreeableness (A) and openness to new experiences (O)) and nine facets of job satisfaction (pay (PAY), promotion (PRM), supervision (SUP), benefits (BEN), rewards (REW), operating conditions (OPC), relation between co-workers (RCW), the nature of 
work (NOW) and communication (COM)) in the study are represented in Table 1 (for those with higher education) and Table 2 (employees with lower level of education). According to the research results represented within the Tables 1 and 2, there are also significant correlations between certain facets of job satisfaction and the personality dimensions of employees.

Table 1: Correlation between all personality dimensions and all facets of job satisfaction with high level of education

\begin{tabular}{|c|c|c|c|c|c|c|c|c|c|c|c|c|c|c|c|c|}
\hline & Mean & SD & 1 & 2 & 3 & 4 & 5 & 6 & 7 & 8 & 9 & 10 & 11 & 12 & 13 & 14 \\
\hline 1.PAY & 262 & 89 & 1 & & & & & & & & & & & & & \\
\hline 2.PRM & 292 & .79 & 249 & 1 & & & & & & & & & & & & \\
\hline 3.SUP & 4.14 & 96 & $329^{\circ}$ & $290^{\circ}$ & 1 & & & & & & & & & & & \\
\hline 4.BEN & 281 & 89 & $459^{\circ}$ & $391^{*}$ & $256^{\circ}$ & 1 & & & & & & & & & & \\
\hline 5.REW & 274 & 83 & $549^{\circ}$ & $351^{\prime \prime}$ & $427^{\circ}$ & $461^{\prime \prime}$ & 1 & & & & & & & & & \\
\hline 6.OPC & 3.61 & 80 & -029 & -006 & -104 & .127 & -010 & 1 & & & & & & & & \\
\hline 7.RCW & 4.14 & .71 & $289^{\circ}$ & .124 & $567^{\circ}$ & $343^{\circ}$ & 207 & -.053 & 1 & & & & & & & \\
\hline 8.NOW & 384 & .98 & .177 & $255^{\circ}$ & $279^{\circ}$ & $-\infty 01$ & $285^{\circ}$ & $-382^{\prime}$ & .194 & 1 & & & & & & \\
\hline $9 . \mathrm{COM}$ & 3.12 & 1.16 & $353^{\circ}$ & $316^{\circ}$ & $465^{\circ}$ & $289^{\circ}$ & $365^{\circ}$ & -.093 & $380^{\circ}$ & .178 & 1 & & & & & \\
\hline $10 . E$ & 5.44 & 123 & -148 & .041 & .119 & -208 & -121 & -110 & .112 & .165 & -019 & 1 & & & & \\
\hline 11.0 & 5.49 & 1.07 & -241 & -135 & .043 & $-280^{\circ}$ & -138 & -086 & -054 & .017 & .049 & $660^{\circ}$ & 1 & & & \\
\hline $12 \mathrm{~A}$ & 5.70 & 1.08 & -059 & -118 & .065 & -016 & -024 & .063 & 254 & .023 & .151 & $382^{\circ}$ & $449^{\circ}$ & 1 & & \\
\hline $13 . \mathrm{C}$ & 6.11 & 84 & -293 & -073 & .081 & -314 & -205 & .048 & .110 & .088 & -0.042 & $500^{\circ}$ & $544^{*}$ & $.532^{\circ}$ & 1 & \\
\hline $14 . \mathrm{N}$ & 3.97 & 121 & .024 & -047 & .01 & 226 & .085 & .132 & .121 & -128 & 249 & .002 & .108 & 246 & -172 & 1 \\
\hline & & & & $\because, c$ & irrelat & on is si & gnific & $t$ at the & $0.01 \mathrm{a}$ & and 0.0 & 5 leve & (2-tail & & & & \\
\hline
\end{tabular}

According to the research results represented in the Table 2, the correlation coefficient between the variables conscientiousness and the pay facet of job satisfaction in the sub-sample of the employees with higher education is negative and significantly different from zero $\left(r=-0.293^{*}, p=.021\right)$, which is not the case in the sub-sample of the employees without higher education degree $(r=-0.123, p=$ $.375)$.

The correlation coefficient between the variables conscientiousness and the benefits facet of job satisfaction in the sub-sample of the employees with higher education is negative and significantly different from zero $\left(r=-0.314^{*}, p=.013\right)$, which is not the case in the sub-sample of the employees without higher education $(r=-0.252, p=.066)$.

Furthermore, the correlation coefficient between the variables openness to new experiences and the benefits facet of job satisfaction in the sub-sample of the employees with higher education is negative and significantly different from zero $\left(r=-0.280^{*}, p=.028\right)$, which is not the case in the sub-sample of the employees without higher education degree $(r=-0.163, p=.239)$. 
In addition, the correlation coefficient between the co-workers' facet of job satisfaction and agreeableness in the sub-sample of the employees with higher education is positive and significantly different from zero $\left(r=0.254^{*}, p=.046\right)$, which is not the case in the sub-sample of the employees without higher education degree $(r=-0.172, p=.213)$.

Table 2: Correlation between all personality dimensions and all facets of job satisfaction with low level of education

\begin{tabular}{|c|c|c|c|c|c|c|c|c|c|c|c|c|c|c|c|c|}
\hline & Mean & SD & 1 & 2 & 3 & 4 & 5 & 6 & 7 & 8 & 9 & 10 & 11 & 12 & 13 & 14 \\
\hline 1.PAY & 284 & 97 & 1 & & & & & & & & & & & & & \\
\hline 2PPQM & 3.00 & .87 & $416^{\circ}$ & 1 & & & & & & & & & & & & \\
\hline 3.SUP & 4.46 & 89 & 243 & .160 & 1 & & & & & & & & & & & \\
\hline 4. BEN & 291 & .86 & $.45 T^{\circ}$ & 225 & -128 & 1 & & & & & & & & & & \\
\hline 5.REW & 278 & .87 & $.563^{\prime \prime}$ & 219 & .162 & $.410^{-\prime}$ & 1 & & & & & & & & & \\
\hline 6. OPC & 3.50 & 65 & -132 & .024 & -.085 & -250 & -144 & 1 & & & & & & & & \\
\hline 7.RCW & 4.42 & .72 & -.008 & .151 & $.383^{\circ}$ & .181 & .101 & -147 & 1 & & & & & & & \\
\hline 8. NOW & 4.11 & 84 & -.005 & .062 & $396^{\circ}$ & .077 & .032 & -.016 & $292^{\circ}$ & 1 & & & & & & \\
\hline $9 . \infty \mathrm{M}$ & 3.46 & $\infty$ & $314^{\circ}$ & -.041 & 203 & $.320^{\circ}$ & $.472^{\prime \prime}$ & -124 & 207 & .092 & 1 & & & & & \\
\hline 10.E & 5.76 & 1.14 & -.167 & .057 & $.292^{\prime}$ & -.045 & .072 & .008 & .178 & .137 & .071 & 1 & & & & \\
\hline 11.0 & 5.44 & 1.00 & -191 & .073 & .128 & $-1 \mathfrak{3}$ & .087 & .018 & .115 & -.064 & .051 & $599^{\circ}$ & 1 & & & \\
\hline $12 \mathrm{~A}$ & 5.86 & 1.12 & -.050 & -.015 & .035 & -112 & .087 & -.024 & -172 & .022 & -.084 & $.564^{\prime \prime}$ & $584^{\circ}$ & 1 & & \\
\hline $13 \mathrm{C}$ & 6.16 & .96 & -123 & .054 & -.050 & -252 & -.009 & .116 & -150 & .040 & -127 & $319^{\circ}$ & $.530^{\circ-}$ & $.731^{*}$ & 1 & \\
\hline $14 . \mathrm{N}$ & 4.52 & 1.30 & .094 & -.012 & -100 & .196 & .050 & -.114 & -012 & -.318 & .103 & .116 & .023 & .020 & -.072 & 1 \\
\hline & & & & $\because$. & orrela & on is : & gnifica & at $t$ & 0.01 & and 0.0 & 5 leve & (2-ta & & & & \\
\hline
\end{tabular}

In the case of employees without higher education, according to the research results, the correlation coefficient between the variables extraversion and the supervision facet of job satisfaction is positive and significantly different from zero $\left(r=0.292^{*}, p=.032\right)$, which is not the case in the sub-sample of the employees with higher education degree $(r=0.119, p=.355)$.

Finally, the correlation coefficient between the negative affectivity and the nature of work facet in the sub-sample of the employees without higher degree of education is negative and significantly different from zero $\left(r=-0.318^{*}, p=.019\right)$, which is not the case in the sub-sample of the employees with higher education ( $r=$ $-0.128, p=.322$ ).

\section{Discussion}

Conscientiousness and the pay facet of job satisfaction. The research results indicated that, in the sub-sample of the employees with higher education degree, an increase in personality dimension labeled as conscientiousness is followed by a 
decrease in pay, which is not the case in the sub-sample of the employees without higher education degree. Considering the complexity of the business tasks placed in front of the employees with higher education, but also considering the importance of the conscientiousness for achieving business success, responsibility throughout the business performance of employees characterized by this personality dimension should be appropriately evaluated by increasing their personal incomes.

For the purpose of this research, conscientiousness was evaluated on the basis of different items, including the one related to expressing the respondents' attitude towards the fact if "they perform high-quality tasks in business environment". According to the theory of fairness, it is understandable that employees with a serious and responsible approach in performing their business tasks could be disappointed if they perceive equalization in their business environment (such as linear payment for their colleagues who are not equally dedicated towards achieving the organizational goals).

As this research was conducted within the organization that is operating in a bureaucratic system since the time of socialism, the salaries were mostly established based on the employees' education degree. This manner of valorization of business performances through personal incomes could be a cause of dissatisfaction with the salaries among the conscientious employees in the organization with higher education degree and good performances.

Conscientiousness and the benefits facet of job satisfaction. The research results indicated that, within the sub-sample of the employees with higher education, an increase in the personality dimension defined as conscientiousness is followed by a decrease in benefits of job satisfaction. The explanation is analogous to the previous one.

Openness to new experiences and the benefits facet of job satisfaction. The research results indicated that, in the case of the employees with higher education degree, an increase in their personality dimension, labeled as openness to new experiences, is followed by a decrease in the benefits facet of job satisfaction. The explanation of this result is similar to the previous one. Thus, the employees evaluated their dimension of personality, defined as openness to new experiences, based on different items, including the following ones: "I prefer the complex approach to analysis of different problems" and "I am creative when performing my business tasks".

High grades provided by the respondents regarding the aforementioned items are important predictors for successful realization of business tasks, especially among the employees with higher education, throughout their confrontation with the complex business tasks. The employees from the sub-sample of the respondents with higher education degree, who provided the high grades when evaluating these 
items, expect an adequate compensation for their successful business engagement based on various benefits.

Agreeableness and the co-workers facet of job satisfaction. In the sub-sample of the employees with higher education, an increase in the personality dimension, labeled as agreeableness, is followed by an increase in the co-workers' component in general job satisfaction. This personality dimension is evaluated based on different items, such as: "I care for establishing good relations with other people in the organization", "I am prone to forgiveness" and "I am sympathetic towards other people". Employees who highly evaluated these items indicated tolerance and empathy for other people in organizational environment, which is an important element for establishing and maintaining good interpersonal relations.

Nowadays, with a high degree of alienation, agreeableness is highly evaluated among people in the organization, due to intense interactions between the coworkers. An employee who sympathizes with a colleague in a difficult situation, providing the support and tolerance at the same time, is usually perceived as an acceptable associate in the organizational environment. In return, colleagues usually tend to "supply" this employee with support, based on reciprocity, while conflicts that such person might experience in the business environment are rare. In the situation of mutual understanding, including the lack of conflict within the workplace, the evaluation of co-workers' job satisfaction is high for all of the employees.

Therefore, the high level of co-workers' job satisfaction among the employees with higher education might be the consequence of high degree of mutual understanding and providing the support, but also the consequence of high degree of co-workers' competences (which is an important item in evaluating co-workers' job satisfaction, which is also related to employees' education degree in significant percentage). Collaboration through team work is more characteristic for the employees with higher education degree and it implies the necessity for demonstrating the tolerance for the possible failures of other team members and for providing help in the process of solving business tasks. The employees with higher education degree would show greater willingness for tolerating the mistakes of coworkers' with higher education degree, due to the fact that their mistakes are, therefore, very rare.

Extraversion and the supervision facet of job satisfaction. In the total sample of this survey research, or more precisely in the sub-sample of the employees without higher education degree, obtained results showed that an increase in the personality dimension, labeled as extraversion, is followed by an increase in their supervisors' component, which is not the case in the sub-sample of the employees with higher education degree. 
Among the items for evaluating the supervision facet of job satisfaction, there was one item considering the level of managers' competences. In monopolistic companies, managers are usually not placed on specific job positions due to their expertise (especially those belonging to top management), which could be clearly perceived by the employees with higher education degree. Such managers are also aware of this fact, so they could experience a higher degree of extraversion among the employees with higher education degree, as a desire for their emphasis, which could further cause the negative implications, in relation of these employees towards their subordinates. Thus, if the employees perceive a low level of fairness in progressing within the organizational hierarchy, it could cause their reduced degree of supervision in job satisfaction.

Employees without higher education degree are usually less "strict" in evaluating the competences of their supervisors or they hesitate to express their possible negative attitude towards the competence of their manager, in comparison to the extent of that readiness among the employees with higher education degree.

Thus, the employees with higher education degree who highly evaluated the personality dimension, labeled as extraversion, are ready to express their opinions more freely (even when it is critical), which could be interpreted by the manager of these employees as a lack of respect for his/her authority. In this way, it is possible to explain why the co-workers' component in job satisfaction is higher among the extravert employees without higher education degree, in comparison to the subsample of extravert employees with higher education degree.

Negative affectivity and the nature of work in job satisfaction. The research results indicated that, in the sub-sample of the employees without higher education degree, the nature of work component is reduced, in the situation when the personality dimension, labeled as negative affectivity, increases.

The respondents without high level of education degree are usually employed at the job positions that are mostly routine, while a part of these employees work on really difficult job positions, therefore, the increase in a degree of negative affectivity could contribute to even higher dissatisfaction with the nature of work component.

Evaluation of the employees' nature of work in job satisfaction comprised different items, including the following one: "Sometimes I have the feeling that my job is meaningless". If the employee has an experience of joblessness, it is understandable that such an employee could not be satisfied with the job itself. It is usual that conditions for performing the business tasks by the employees without higher education degree are very difficult. Due to difficult business conditions, it is not surprising that the employees without higher education degree expressed low grades for the item "I like to perform the job within my workplace". 
On the other hand, the items for evaluating the personality dimension, labeled as the negative affectivity, also included different items, including the following one: "I am prone to negative interpretation of the past, but also the possible future events" (which is characteristic for the miners). Thus, the real high risk of the job for the workers in the researched organization, reduces their satisfaction with the work itself.

Unlike fifty years ago, when mining profession was highly respected and recognized by the wider community, the situation has changed nowadays, which contributed to reduced evaluation of the miners regarding the nature of the work facet of job satisfaction.

\section{Conclusion}

Due to a decreased possibility that high level of employees' conscientiousness and their good business performance will influence their salaries (according to a prescribed system that usually links the amount of salary with related education degree), managers should be able to identify and evaluate the business performance of such employees by various benefits (such as providing free holidays within the organizational resort, or providing incentive travels). Such a manager's attitude towards the employees with high degree of conscientiousness and business performance will positively influence their motivation, on the one hand, while, on the other, it might increase the benefits of job satisfaction, at the same time.

Given that employees with a pronounced dimension of personality, labeled as openness to new experiences, are characterized by curious nature and wide interests, the management of the organization could increase the level of their general job satisfaction based on different benefits for such employees, enabling them to participate in various trainings (such as foreign language courses, or seminars for acquiring additional knowledge in specific profession).

The management should take into consideration the personality dimension of employees, labeled as agreeableness, when forming the organizational team. It is also important to form a team that will work harmoniously without conflicts. The presence of the team members with the high level of personality dimension, labeled as agreeableness, could contribute to such a situation, but it also depends on adequate expertise of other team members.

In jobs that do not require a high degree of expertise, it should be possible (if the nature of job allows it) to enrich the business tasks and reduce the high level of routine for employees, in order to increase the employees' satisfaction with the nature of work. Additionally, security measures for safe work at risky job positions should be maximized, while the miners should be rewarded in the appropriate manner for their business results, making it clear that their work is important for the entire community. 


\section{Acknowledgment}

Acknowledgments: This research is part of the project 'Transformation of geospace in Serbia - past, current problems and solution proposals', approved by the Ministry of Education, Science and Technological Development of Republic of Serbia (project registration number: 176020 OI).

\section{References}

Aleksić-Glišović, M., Jerotijević, G. and Jerotijević, Z. (2019). Modern approaches to employee motivation. Ekonomika, 65 (2), 121-133.

Antoncic, B., Bratkovic Kregar, T., Singh, G. and DeNoble, A. F. (2015). The Big Five Personality-Entrepreneurship Relationship: Evidence from Slovenia. Journal of Small Business Management, 53 (3), pp. 819-841.

Arthaud-Day, M. L., Rode, J. C. and Turnley, W. H. (2012). Direct and contextual effects of individual values on organizational citizenship behavior in teams. Journal of Applied Psychology, 97 (4), pp. 792.

Atari, M., Barbaro, N., Sela, Y., Shackelford, T. K. and Chegeni, R. (2017). The Big Five personality dimensions and mate retention behaviors in Iran. Personality and Individual Differences, 104, pp. 286-290.

Bui, H. T. (2017). Big Five personality traits and job satisfaction: Evidence from a national sample. Journal of General Management, 42 (3), pp. 21-30.

Burgess, S. M. and Nyajeka, P. (2007). Market orientation and performance in low-income countries: The case of Zimbabwean retailers. Advances in International Management Journal, 20, pp. 215-257.

Burke, R. J., Graham, J. and Smith, F. (2005). Effects of reengineering on the employee satisfaction-customer satisfaction relationship. The TQM Magazine, 17 (4), pp. 358-363.

Chi, C. G., Gursoy, D. (2009). Employee satisfaction, customer satisfaction and financial performance: An empirical examination. International Journal of Hospitality Management, 28 (2), pp. 245-253.

Cronin, J. J. Jr., Brady, M. K. and Hult, G. T. M. (2000). Assessing the effects of quality, value and customer satisfaction on consumer behavioral intentions in service environments. Journal of Retailing, 76 (2), pp. 193-218.

Frye, W. and Mount, D. (2007). An examination of job satisfaction of general managers based on hotel size and service type. Journal of Human Resources in Hospitality \& Tourism, 6 (2), pp. 109-134.

Fu, W. and Deshpande, S.P. (2014). The impact of caring climate, job satisfaction and organizational commitment on job performance of employees in a China's insurance company. Journal of Business Ethics, 124 (2), pp. 339-349.

Hahn, E., Gottschling, J., König, C. J. and Spinath, F. M. (2016). The heritability of job satisfaction reconsidered: Only unique environmental influences beyond personality. Journal of Business and Psychology, 31 (2), pp. 217-231.

Héder, M., Szabó, S. and Dajnoki, K. (2018). Effect of labour market changes on HR functions. Anali Ekonomskog fakulteta u Subotici, 39, pp. 123-138. 
Howard, P. J. and Howard, J. M. (2000). The owner manual for personality at work: How the Big Five Personality Traits affects Your performance. Bard Press: Communication, Teamwork, Leadership and Sales.

İrengün, O. and Arıkboğa, Ş. (2015). The effect of personality traits on social entrepreneurship intentions: A field research. Procedia-Social and Behavioral Sciences, 195, pp. 11861195.

Ivanović-Đukić, M., Đorđević, B. and Lepojević, V. (2018). Mediating effects of educational level on job related characteristics: Job satisfaction relationship. Strategic Management, 23 (2), pp. 13-21.

Judge, T. A. and Zapata, C. P. (2015). The person-situation debate revisited: Effect of situation strength and trait activation on the validity of the Big Five personality traits in predicting job performance. Academy of Management Journal, 58 (4), pp. 1149-1179.

Li, C-H. and Chang, C-M. (2016). The influence of trust and perceived playfulness on the relationship commitment of hospitality online social network-moderating effects of gender. International Journal of Contemporary Hospitality Management, 28 (5), pp. 924-944.

Liang, C. T., Chia, T. L. and Liang, C. (2015). Effect of personality differences in shaping entrepreneurial intention. International Journal of Business and Social Science, 6 (4.1), pp. 166-176.

Locke, E. A. (1976). The nature and causes of job satisfaction, in Dunnette, M.D. (ed.), Handbook of industrial and organizational psychology (1927-1950). Chicago: Rand McNally.

Lopez, T. B., Babin, B. J. and Chung, C. (2009). Perceptions of ethical work climate and personorganization fit among retail employees in Japan and the US: A cross-cultural scale validation. Journal of Business Research, 62 (6), pp. 594-600.

Maruping, L. M. and Magni, M. (2012). What's the weather like? The effect of team learning climate, empowerment climate and gender on individuals' technology exploration and use. Journal of Management Information Systems, 29 (1), pp. 79-113.

Rammstedt, B., Danner, D. and Martin, S. (2016). The association between personality and cognitive ability: Going beyond simple effects. Journal of Research in Personality, 62, pp. 39-44.

Spector, P. E. (1997). Job Satisfaction: Application, Assessment, Causes and Consequences. Sage Publications.

Sun, J., Kaufman, S. B. and Smillie, L. D. (2018). Unique associations between big five personality aspects and multiple dimensions of well-being. Journal of personality, 86 (2), pp. 158-172.

Therasa, C., \& Vijayabanu, C. (2015). The impact of Big Five personality traits and positive psychological strengths towards job satisfaction: A review. Periodica Polytechnica Social and Management Sciences, 23(2), pp. 142-150.

Van Den Berg, P. T. and Pitariu, H. (2003). The Big Five and well-being outcomes during the revolution in Romania. Cogniţie Creier Comportament, 7 (4), pp. 307-320.

Walker, M. and Vetter, T. (2016). Personality Processes and Individual Differences: Changing the personality of a face: Perceived Big Two and Big Five personality factors modeled in real photographs. Journal of Personality and Social Psychology, 110 (4), pp. 609-624.

http://www.eps.rs/lat/kolubara/Stranice/O\%20nama/ljudski-resursi.aspx, retrieved in December, 2019. 


\section{UTICAJ NIVOA OBRAZOVANjA ZAPOSLENIH NA KORELACIJU IZMEĐU ZADOVOLJSTVA POSLOM I DIMENZIJA LIČNOSTI}

Rezime: Zadovoljstvo poslom zaposlenih predstavlja važan faktor u oblikovanju organizacionih poslovnih performansi. Međutim, zadovoljstvo poslom može zavisiti od dimenzija ličnosti zaposlenih, kao što su: ekstraverzija, neuroticizam, savesnost, prijatnost i otvorenost za nova iskustva. Pored toga, stepen obrazovanja zaposlenih može uticati i na zadovoljstvo poslom zaposlenih, ali i na dimenzije njihove ličnosti. U skladu sa tim, ovo istraživanje je orijentisano na utvrđivanje uticaja stepena obrazovanja zaposlenih na korelaciju između zadovoljstva poslom zaposlenih i njihovih dimenzija ličnosti. Istraživanje je obuhvatilo uzorak od 116 ispitanika, zaposlenih $\mathrm{u}$ velikoj monopolističkoj organizaciji, orijentisanoj ka energetskom sektoru, koja posluje u tranzicionom društvu. Rezultati istraživanja pokazuju da stepen obrazovanja zaposlenih utiče na korelaciju između svih dimenzija ličnosti, s jedne strane, i plate, benefita, odnosa sa saradnicima, supervizorima i prirode posla, kao važnih aspekata zadovoljstvom poslom, sa druge strane. Pored teorijskog doprinosa, rezultati istraživanja mogu imati i praktične implikacije na osnovu pružanja informacija za unapređenje pitanja koja se tiču upravljanja ljudskim resursima u Srbiji, gde su opšti uslovi poslovanja različiti u poređenju s razvijenim zemljama.

Ključne reči: zadovoljstvo poslom, dimenzije ličnosti, teorija Velikih pet, nivo obrazovanja, tranziciono društvo

\section{Authors' biographies}

Milena Nedeljković Knežević graduated with $\mathrm{PhD}$ in Human resource management in 2009 at the Faculty of technical sciences, University of Novi Sad. Second PhD dissertation she defended in 2016, in the area of Behavioral economics at the Faculty of economic and Faculty of philosophy (interdisciplinary), University of Novi Sad. She is employed as Associate professor at the Faculty of sciences, University of Novi Sad. She has published 2 monographs and over 20 scientific journal articles, and her research interests are within the area of management, management of human resources and entrepreneurship.

Sladjana Nedeljković, graduated in 2016 with interdisciplinary $\mathrm{PhD}$ in sociology and tourism at the University of Novi Sad. She is employed at the mining basin "Kolubara". Actively engaged in organization and lecturing at cultural and humanitarian manifestations. Research interests: cultural tourism, sociology of culture, organizational culture.

Maja Mijatov, PhD, is a Research Associate at the Faculty of Sciences, Department of Geography, Tourism and Hotel Management (University of Novi Sad). Her main fields of interest are business ethics, ethical climate, corporate social responsibility, business performances, job satisfaction, organizational commitment, service orientation, human resources. She is an author and co-author of different papers presented throughout the conferences (in Serbia and abroad) and within different academic publications. During the studies, she gained the numerous scholarships. 